\title{
Export of medicinal and aromatic plant materials from Nepal
}

\author{
Suresh K Ghimire ${ }^{1 *}$, Bandana Awasthi ${ }^{1}$, Santhosh Rana ${ }^{1}$, Hum Kala Rana ${ }^{1}$, Rameshwar Bhattarai ${ }^{2}$ and \\ Dipesh Pyakurel ${ }^{3}$ \\ ${ }^{1}$ Central Department of Botany, Tribhuvan University, Kirtipur, Kathmandu, Nepal \\ ${ }^{2}$ Green Era Pvt. Lt., Kathmandu, Nepal \\ ${ }^{3}$ Agriculture and Forestry University, Rampur, Chitwan, Nepal
}

\begin{abstract}
Medicinal and aromatic plants (MAPs) have been identified as one of the potential high value commodities in Nepal with huge prospects for economic development. However, data about MAP consumption, volumes of trade and levels of demand are inadequate. In Nepal, there is a general lack of reliable trade data that constrains the estimation of total amount of MAPs in trade. This study aims to assess current trends in volume and value of MAP commodities exported from Nepal and identify the major destination countries. We mainly used formal trade data of Nepalese MAP products over the last 10 years (2005 to 2014 ) from the repository of UN COMTRADE database accessed via TRADE MAP. Results indicated that the export value of MAP products increased from USD 27.49 million in 2005 to USD 60.09 million in 2014 (mean for the last 10 years being USD 39.34 million) and this increment is primarily due to increase in price, as the trade volume follows decreasing trend over the same periods. The average annual export amount of Nepalese MAP products for the last 10 years has been calculated to be 13.23 thousand tons (range 10.77-20.25 thousand tons). The rise in export value of MAP products indicates increasing demand of MAPs globally. Nepalese MAP commodities were exported to almost 50 destinations. In terms of volume, India has been the major importer of MAP materials all these years. However, China stood top among the countries sharing high value to Nepalese MAP trade. The trade statistics show that, for the total trade value considering the MAP materials at broad category, the export of products (e.g., spices and flavors) other than listed in HS code 1211 should also be considered for appropriate valuation. Despite the decrease in trade amount, spices and flavors have fetched a gradually increasing price per unit volume which is apparent by the fact that these herbs have ever increasing market demand. Nepal can reap maximum benefit from growing international demand of MAPs given that Government impose strict check in borders to minimize the underestimation, train concerned authorities in proper identification of MAPs products and help to develop species-specific 8- and 10-digit HS Codes for proper documentation of imports and exports of MAPs products.
\end{abstract}

Key-words: database, destination countries, Himalaya, MAP trade, trade value.

\section{Introduction}

Medicinal and aromatic plants (MAPs) are one of the most important components of non-timber forest products (NTFPs) extracted from natural ecosystems or managed forests and have high social-cultural and economic values. MAPs play key role in primary health care and in generating income for people mostly in developing countries. MAPs cover plants not only used strictly for medicinal purposes, but also includes plants used for food, condiment, cosmetics and fragrance, and for other purposes (Schippmann et al. 2002; Hamilton 2004). Therefore, MAPs now serve as high potential raw materials for the growing pharmaceutical industry as well as for the nutraceuticals and cosmeceuticals (Marriott 2000; Pieroni et al. 2004; Barnes and Prasain 2005).

MAPs have been identified as one of the potential high value commodities in Nepal with huge prospects for economic development. MAP subsector has been given high importance by the Government of Nepal in its policies and programs with an aim to reduce poverty while conserving biodiversity (DPR
2006). It has been estimated that about 143-161 species of NTFPs, including MAPs are harvested for commercial purpose in Nepal (Bhattarai and Ghimire 2006; Subedi 2006).

Nepal has been regarded as one of the important reservoirs for the supply of MAPs in Asia, including India and China (Malla et al. 1995; Olsen and Helles 1997 a,b; Ghimire 1999; Olsen and Larsen 2003; Olsen 2005a; Pyakurel and Oli 2013). The volume and value of MAP trade rapidly expanded over the last decade due to increasing demand for natural products from the international market and in particular from the Indian and Chinese pharmaceutical and aromatic industries (Vasisht et al. 2016). The popularity of plant-based food supplements, cosmetics, dyeing and coloring agents over synthetic ones has accelerated the international demand of MAPs and products. However, data about MAP consumption, volumes of trade and levels of demand are inadequate. In Nepal, there is a general lack of reliable trade data that constrains the estimation of total amount of MAPs in trade. Department of Forests, Ministry of Forests and Soil Conservation of Government of 
Nepal annually publishes the quantity collected and revenue generated from MAPs but the quantification is far lower than expected (Maraseni et al. 2006; Humagain and Shrestha 2009). There are thus large variations in the estimates of volume of trade showing the difficulty of actually estimating the amount collected due to lack of transparency in the market circuit. The estimates on the value of MAP trade in the past were mainly based on the export data between Nepal and India and those even varied greatly according to the author. Estimates of annual export value of MAPs from Nepal in the last two decades ranged USD 3.0-35.0 million with annual amount ranging around 3,500-15000 tons (Edwards 1996; Olsen 2005b; Subedi 2006). Estimates so far made on MAP trade in Nepal, mainly based on Indian market, do not represent the real trade scenario as the volume and value of trade has dramatically increased with increasing demand from overseas markets and that from China (Pyakurel and Oli 2013). Therefore, the aim of this study is to assess the current trends in volume and value of MAP products exported from Nepal and identify the major destination countries for Nepalese MAPs.

\section{Materials and Methods}

\section{TRADE OF MAP PRODUCTS: DATA SOURCES}

In this study, an attempt has been made to summarize formal data on MAP products exported from Nepal based on UN COMTRADE statistics. We analyzed the official trade statistics of Nepalese MAPs for 10 years between 2004 and 2014. UN COMTRADE (United Nations International Trade Statistics Database) is a repository of official international trade statistics and relevant analytical tables maintained by United Nations Statistics Division (UNSD). More than 170 countries provide their annual international trade data to the database and these data are subsequently transformed into the UNSD standard format with consistent coding (UNSD 2015). UN COMTRADE database was accessed via TRADE MAP (trade statistics for international business development), which is a market analysis tool developed by the International Trade Centre (ITC), a joint agency of the United Nations and the World Trade Organization (WTO).

In Nepal, District Forest Offices issue transport permit (required to transport MAPs out of the district of origin) and the data is compiled and published by Department of Forests (DoF) on annual basis. In this study, we also referred MAPs trade data from DoF (DoF 2006-2015) to compare that of UN COMTRADE data.

\section{MAP PRODUCTS AND CATEGORIES}

In UN COMTRADE database, all the export commodities are treated under specific codes, known as harmonized system (HS) code. The harmonized system is an international nomenclature defined by the World Customs Organization (WCO) for the classification of products. The HS for classifying goods is a six-digit code system. Individual countries may extend this to 10 digits for import and 8 digits for export. Most of the studies narrating the export of medicinal plants from Nepal, so far, considered the products listed under HS code 1211 as medicinal and aromatic plants (MAPs). This code covers raw plants and parts of plants (fresh, chilled, frozen or dried, cut or uncut, crushed or powdered) including seeds and fruits, of a kind used primarily in perfumery, in pharmacy or for insecticidal, fungicidal or similar purposes. HS code 1211 , however, does not cover other raw aromatic plant products that also fall under the broad definition of MAPs (materials and products), including spices and flavors, plants producing dyes, tannins and plant gums, and processed (essential oils, and other extracts) and finished products (e.g., traditional medicines) (Schippmann et al. 2002; Hamilton 2004). These latter products are treated under separate HS codes (Table 1). For example, raw aromatic products (spices and flavors) are covered under HS codes 0904, 0906, 0908 and 0910; each of these are further classified into different categories with 6-digits HS code (Table 1). Similarly, essential oil is covered under HS code 3301 with as many as 8 categories with 6-digits HS code (Table 1). MAPs and their products specified under each HS code usually represent products of different types identified by a broad product name and thus they are not distinguished at the species level. In this study, altogether 33 different categories (with 6-digits HS code) of products listed under seven 2-digit HS codes and thirteen 4-digit HS codes are treated broadly as MAP products and materials (Table 1).

\section{DATA ANALYSIS}

Official international trade statistics of Nepalese MAPs of the past 10 years (between 2005 and 2014) were analyzed with descriptive statistics and presented in table and graphs showing trends over time. The COMTRADE data is classified according to HS codes (Table 1). Our analyses did not take into account herbs which are traded without documentation or those banned by the government, and also lack other aspects of economic valuation of products and services (Banjade and Paudel 2008).

\section{Results}

Official trade statistics of UN COMTRADE accessed via TRADE MAP for the last 10 years (2005-2014) showed that Nepal, in average, exported 32.62 thousand tons of NTFP annually with an average value of USD 55.94 million. The export value is equivalent to NPR 544.41 crore using the mean conversion rate of USD $1=$ NPR 97.32 for 2014. MAP products have a share of $40.89 \%$ and $69.87 \%$ to the total NTFP export in terms of volume and value, respectively. Nepal exported about USD 27.49 million worth of MAPs to the world in 2005, which increased to USD 41.50 million in 
Table 1. Summarized MAP categories with corresponding HS codes. The HS codes cover MAP products exported from Nepal.

\begin{tabular}{|c|c|c|c|}
\hline $\begin{array}{l}\text { HS codes } \\
\text { (2-digits) }\end{array}$ & MAP Category & HS codes (4 and 6-digits) & Product code-wise sub-categories \\
\hline \multicolumn{4}{|c|}{ A. Raw plant products } \\
\hline 07 & $\begin{array}{l}\text { Wild mushrooms and } \\
\text { health foods }\end{array}$ & $0712(071231,071239)$ & Mushrooms and truffles \\
\hline \multirow[t]{4}{*}{09} & Spices and flavors* & $0904(090411,090412)$ & Pepper of the genus Piper, ex cubeb pepper \\
\hline & & $\begin{array}{l}0906(090610,090611,090619, \\
090620)\end{array}$ & Cinnamon and cinnamon-tree flowers \\
\hline & & $0908(090830,090831,090832)$ & Cardamoms \\
\hline & & $0910(091040)$ & Thyme and bay leaves \\
\hline 12 & Plants and part of plants & $\begin{array}{l}1211(121110,121120,121130 \\
121190)\end{array}$ & Medicinal plants \\
\hline \multirow[t]{2}{*}{13} & $\begin{array}{l}\text { Natural gums, resins, } \\
\text { vegetable saps and extracts }\end{array}$ & $1301(130120,130190)$ & $\begin{array}{l}\text { Natural gums, resins, gum-resins, oleoresins, } \\
\text { balsam, Arabic gum }\end{array}$ \\
\hline & & $1302(130211,130219,130239)$ & Vegetable saps and extracts \\
\hline \multirow[t]{2}{*}{32} & Dyes and tannins & $3201(320190)$ & Tannin extract of vegetable origin \\
\hline & & $3203(320300)$ & Coloring matter of vegetable/animal origin \\
\hline \multicolumn{4}{|c|}{ B. Processed plant products (after value-addition) } \\
\hline 33 & $\begin{array}{l}\text { Essential oils, resinoids, } \\
\text { terpenic by-products }\end{array}$ & $\begin{array}{l}3301(330112,330113,330129 \\
330124,330125,330129 \\
330130,330190)\end{array}$ & $\begin{array}{l}\text { Essential oils, resinoids, terpenic by-products } \\
\text { of essential oils }\end{array}$ \\
\hline \multicolumn{4}{|c|}{ C. Finished products } \\
\hline \multirow[t]{2}{*}{30} & $\begin{array}{l}\text { Ayurvedic preparations, } \\
\text { traditional medicines }\end{array}$ & $3003(300390)$ & $\begin{array}{l}\text { Ayurvedic preparations/ traditional medicines, } \\
\text { in bulk }\end{array}$ \\
\hline & & $3004(300490)$ & $\begin{array}{l}\text { Ayurvedic preparations/ traditional medicines, } \\
\text { in doses }\end{array}$ \\
\hline
\end{tabular}

*Spices and flavors of wild or semi-wild habitats; purely cultivated products were excluded.

2010 and reached to USD 60.09 million in 2014 (Figure 1a, Table 2), with the overall average annual export value for the last 10 years (2005-2014) being USD 39.34 million (NPR 382.86 crore).

However, the trend in the amount of MAP export is slightly different. In 2005, about 13.55 thousand tons of MAP products were exported, the amount peaked at 20.25 thousand tons in 2008 and thereafter declined to 13.38 thousand tons in 2010 and further declined to 10.77 thousand tons in 2014 (Figure 1b). The overall average annual export amount for the last 10 years (2005-2014) has been calculated to be 13.23 thousand tons. The export amounts of other NTFPs (other than MAPs) continue to increase from 2011 onwards (Figure 1b).

Based on the analysis of two major raw products, spice and flavors (2-digits HS codes 09; 4-digits HS codes 0904, 0906, 0908 and 0910) and medicinal plants (4-digits HS code 1211), it was revealed that Nepalese MAP products were exported to almost 50 destinations (countries). India has always been the largest importer of raw spices and flavors from Nepal both in terms of volume and value. Pakistan and UAE remained second and third destination country, respectively (Figure 2a,b,
Table 3). The traded quantity of spices and flavors decreased steadily after 2008 but the value of trade recorded steady increase in that same period and beyond, except in 2009 and 2013 (Figure 2a,b).

India also imported highest quantities of medicinal plants (HS code 1211) all over the years between 2005 and 2014 (89.46\% of total export), followed by China (7.82\%) and Pakistan (1.08\%) (Figure 2c, Table 3). But in terms of value, China stood as the top destination country in 2012 and afterwards, and India and Singapore remained the second and third destination country, respectively (Figure 2d). Average trade data of last 10 years showed that China shared $45.58 \%$ of the total value of medicinal plants traded from Nepal, followed by India (32.00\%), Singapore (11.26\%), Hong Kong (6.52\%) and Viet Nam (1.07\%). These facts suggested that China, Singapore, Hong Kong and Viet Nam mainly imported high value products, such as Ophiocordyceps sinensis, that can fetch very high prices in the international market.

We looked at DoF data for the same period (i.e., between 2005 to 2014) to see any variations in traded/exported quantity of medicinal plants (Figure 3 ) with that of UN COMTRADE 

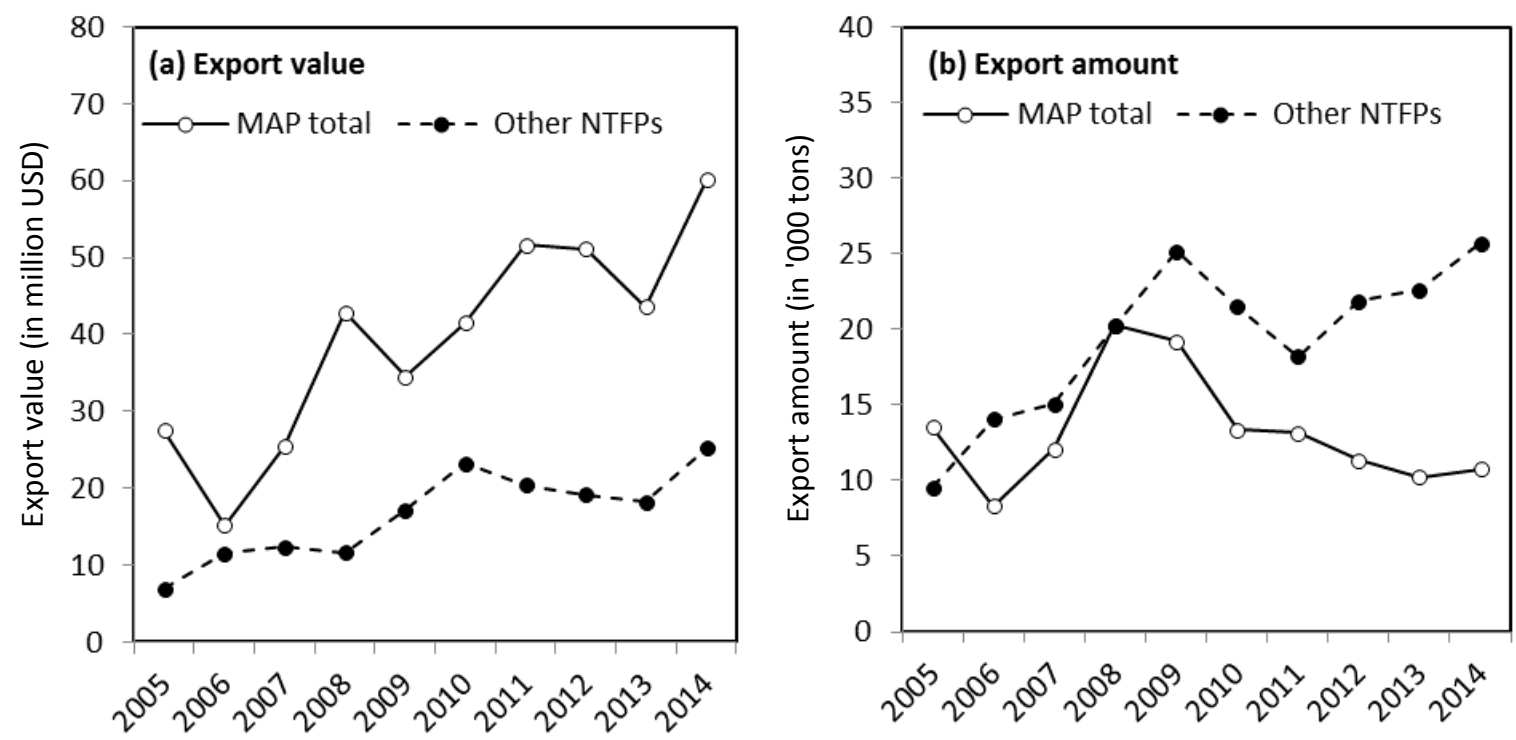

Figure 1. Trend of MAP export: (a) value (in million USD) and (b) amount (in '000 tons) of MAP and other NTFP products exported from Nepal between 2005 and 2014. All export data based on UN COMTRADE statistics accessed via ITC 'Trade Map'. Direct data on exports of MAP products from Nepal to the world in and before 2008 is not available. Thus, the figure between 2005 and 2008 is based on mirror data (the trade of countries that do not report their trade data to UN COMTRADE can be reconstructed on the basis of data reported by partner countries. The data obtained are called mirror data).

statistics. According to DoF data, the volume of medicinal plants trade showed minor fluctuation from 2005 to 2012 ( $\mathrm{min}$ $=2170$ tons in $2010, \max =3380$ tons in 2008), the volume decreased to 1180 tons in 2013 and increased to 4830 tons in 2014 (Figure 3). The 10 years' average annual trade of medicinal plants was 2810 tons. Overall, the annual average quantity of medicinal plants trade based on the DoF data was lower than that of the UN COMTRADE statistics, the latter recorded the average export of 4701 tons (Table 2). More interestingly, the revenue collected by DoF did not match with the quantity traded; the quantity of trade was lower in 2009 but revenue collection was highest in that year (Figure 3).

\section{Discussion}

MAPs have been used in traditional medication for millennia, but introduction of trade opens new avenue for human livelihood by supporting the local economy (Máthé 2015). However, increase in global demand may lead to intense harvesting of MAPs taking their sustainability to an alarming status thereby making conservation and management a key issue (Ghimire et al. 2005; Bhattarai and Ghimire 2006). In order to address the issues appropriately, the foremost need seems to be acknowledging what actually MAPs and their products are and how, where and at what levels are they traded. As for one of the most appropriate definitions

Table 2. Export of MAP products from Nepal between 2005 and 2014. Products are arranged according to product category (see Table 1 for product category and HS Codes).

\begin{tabular}{|c|c|c|c|c|c|c|c|c|}
\hline \multirow{2}{*}{ Product } & \multicolumn{4}{|c|}{ Value (in ‘000 USD) } & \multicolumn{4}{|c|}{ Amount (in tons) } \\
\hline & 2005 & 2010 & 2014 & Mean* & 2005 & 2010 & 2014 & Mean* \\
\hline \multicolumn{9}{|l|}{ A. Raw plant products } \\
\hline Wild mushrooms and health foods & 433 & 121 & 681 & 291 & 2 & 4 & 5 & 6 \\
\hline Spices and flavors & 13508 & 20207 & 28909 & 17711 & 6600 & 4644 & 3965 & 5231 \\
\hline Medicinal plants & 1984 & 4917 & 17320 & 7590 & 4152 & 4379 & 4509 & 4701 \\
\hline Natural gums, resins, vegetable saps and extracts & 258 & 25 & 32 & 85 & 78 & 3 & 2 & 37 \\
\hline Dyes and tannins & 5806 & 9669 & 1994 & 6113 & 1775 & 2776 & 871 & 1954 \\
\hline \multicolumn{9}{|l|}{ B. Products after value-addition (processing) } \\
\hline Essential oils, resinoids, terpenic by-products & 505 & 824 & 1928 & 959 & 31 & 34 & 29 & 35 \\
\hline \multicolumn{9}{|l|}{ C. Finished products } \\
\hline Ayurvedic preparations, traditional medicines & 4994 & 5735 & 9228 & 6592 & 911 & 1545 & 1388 & 1270 \\
\hline Total & 27488 & 41498 & 60091 & 39342 & 13549 & 13383 & 10766 & 13232 \\
\hline
\end{tabular}

*Mean was calculated based on 10 years' export data (from 2005 to 2014). Data source: ITC, Trade Map 2005-2014. Both direct and mirror data are used to calculate the export value and amount. 

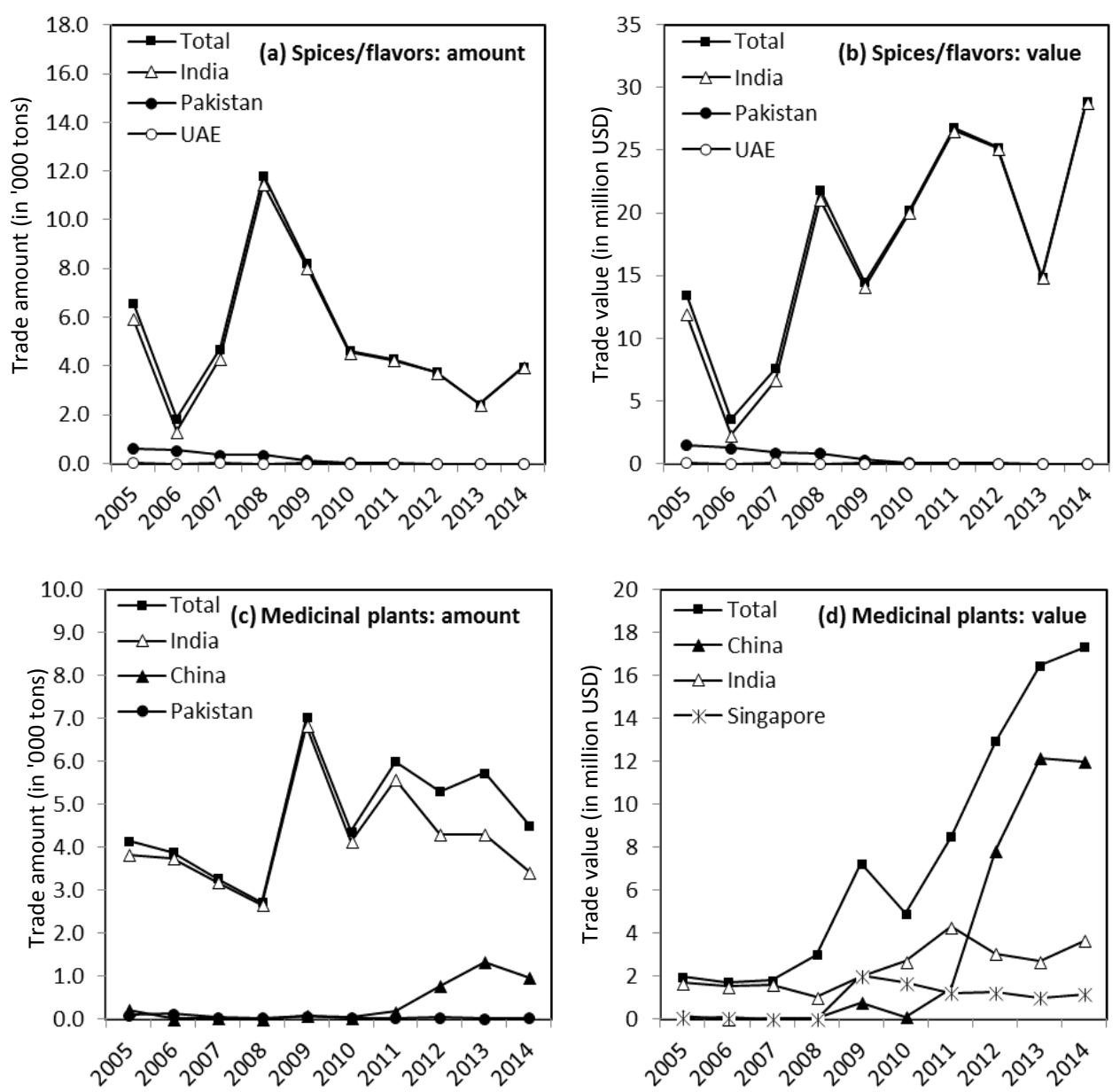

Figure 2. Top 3 export destination countries in terms of trade volume and value of two major raw MAP products (medicinal plants and spices) between 2005 and 2014. The figure between 2005 and 2008 is based on mirror data. All export data based on UN COMTRADE statistics accessed via ITC 'Trade Map'.

Table 3. Major export destination countries (top 5) in terms of trade volume and value of two major raw MAP products: (a) medicinal plants, and (b) spices. Data shown are average volume and value exported to the destination countries from Nepal for last 10 years (between 2005 and 2014). Analysis based on both mirror* (2005 and 2008) and direct (2009-2014) data. All export data based on UN COMTRADE statistics accessed via ITC 'Trade Map'.

\begin{tabular}{llllll}
\hline Country & $\begin{array}{l}\text { Export amount } \\
\text { ('000 tons) }\end{array}$ & $\begin{array}{l}\text { \% Share in } \\
\text { export amount }\end{array}$ & Country & $\begin{array}{l}\text { Export value } \\
\text { (million US\$) }\end{array}$ & $\begin{array}{l}\text { \% Share in export } \\
\text { value }\end{array}$ \\
\hline (a) Medicinal plants & & & & & \\
India & 4.21 & 89.46 & China & 3.46 & 32.00 \\
China & 0.37 & 7.82 & India & 0.43 & 11.26 \\
Pakistan & 0.05 & 1.08 & Singapore & 0.85 & 6.52 \\
Viet Nam & 0.02 & 0.33 & Hong Kong, China & 0.50 & 1.07 \\
Germany & 0.01 & 0.30 & Viet Nam & 0.08 & - \\
\hline Total & 4.70 & - & Total & 7.59 & 96.86 \\
\hline (b) Spices & & & & 17.15 & 2.73 \\
\hline India & 5.01 & 95.71 & India & 0.48 & 0.20 \\
Pakistan & 0.20 & 3.91 & Pakistan & 0.04 & 0.05 \\
UAE & 0.01 & 0.23 & UAE & 0.01 & 0.04 \\
Japan & 0.00 & 0.07 & Korea & 0.01 & - \\
China & 0.00 & 0.02 & United Kingdom & 17.71 & \\
\hline Total & 5.23 & - & Total & & \\
\hline
\end{tabular}

*the trade of countries that do not report their trade data to UN COMTRADE can be reconstructed on the basis of data reported by partner countries; the data obtained are called mirror data. 


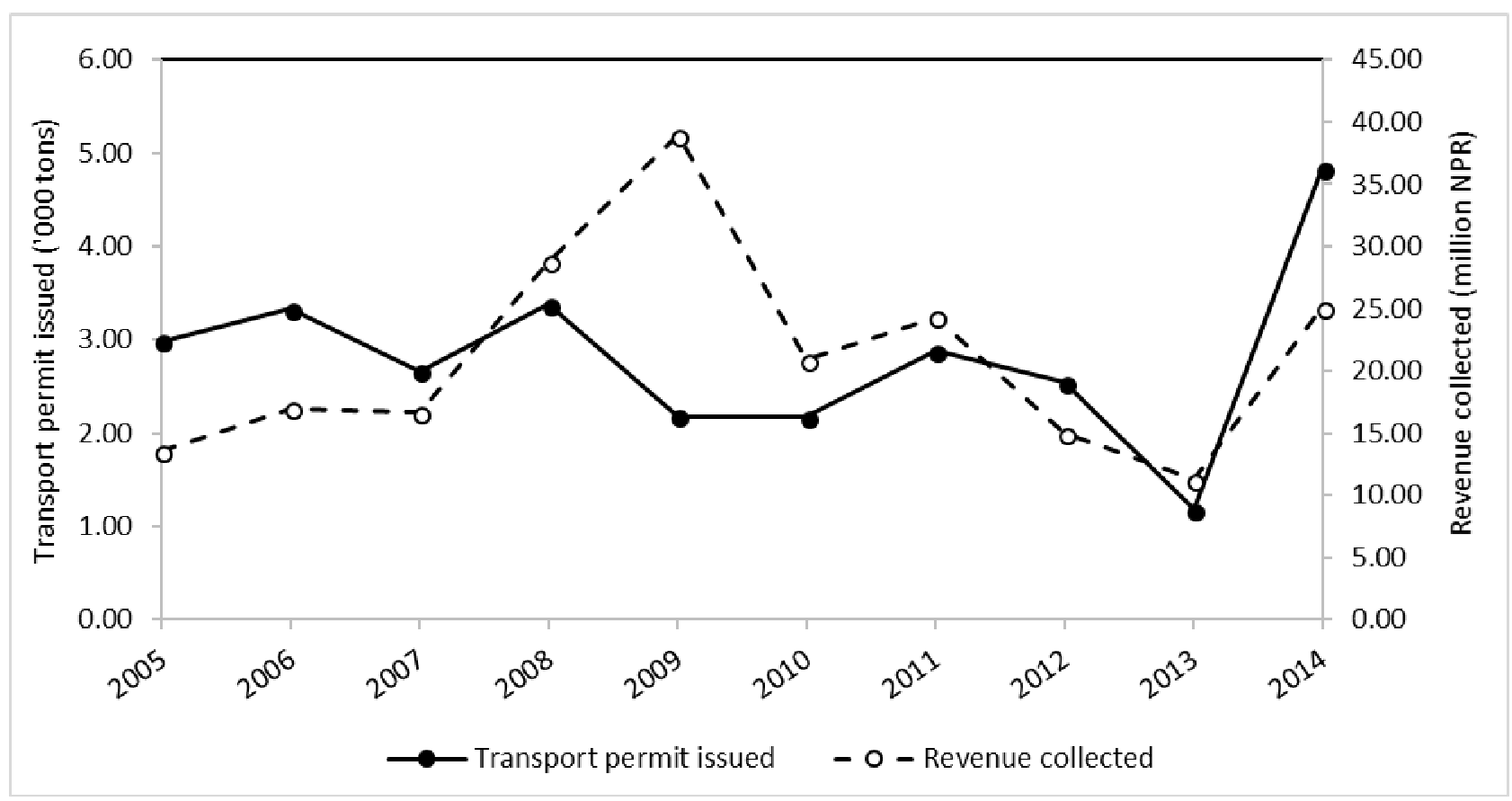

Figure 3. Transport permit for medicinal plants issued, and revenue collected by District Forest Offices from all 75 districts between 2005 and 2014. Data was collected from Department of Forest's annual publications (DoF 2006-2015).

of MAPs, they are botanical raw materials, also known as herbal drugs, primarily used for therapeutic, aromatic and/ or culinary purposes, beauty aids and cosmetics, medicinal products, dietary supplements and other natural health products (Medicinal Plant Specialist Group 2007). HS code 1211, given for medicinal plant products, alone does not represent the complete aspects of MAPs as defined. This suggests that many of the products which actually fall into the category might have been overlooked. Therefore, consideration of HS code 1211 only in trade estimation might have affected total international valuation of MAPs exported from Nepal. Our study, documented the wide varieties of products, some often overlooked to help understanding the contribution and significance of each product in trade.

The rise in export value over the last 10 years (2005 to 2014, Figure 1a) indicates increasing demand of MAPs globally. Our study indicated that the export value of MAP increased from US $\$ 27.49$ million in 2005 to US\$ 60.09 million in 2014 and this increment is primarily due to increase in price, rather than volume as the trade volume follows the decreasing trend especially after 2008 (Figure 1b). It might also suggest that despite people willing to pay high value, the stock of MAPs have actually been decreasing. Also, higher price might have tempted harvesters for premature and over-harvesting, leading to decline in stock (Ghimire et al. 2005). But looking through the contribution of different products (Table 2, Figure 2 ), it shows that it is not medicinal plants which supply has affected the total collection but also the decrease in volume of spices and flavors. Hence, the focus should also be shifted towards the much valuable spices and flavors. Despite the decrease in trade amount (Figure 2a), spices and flavors have fetched a gradually increasing price per unit volume (Figure 2b) which is apparent by the fact that these herbs have ever increasing market demand.

The top destination countries for export of major raw products, spices/flavors and medicinal plants, are Asian. This signifies the expandable scope of regional trade for Nepal. India has been the major importer of MAPs all these years, in terms of volume, which is also supported by earlier studies (Edwards 1996; Olsen 1998; Olsen 2005a,b; Olsen and Helles 1997a,b; Kunwar et al. 2013; Subedi et al. 2013). Despite India being the topmost importer in terms of volume of Nepalese MAPs, China stood top among the countries sharing high value to MAP trade, which is supported by a recent analysis in the international trade of medicinal plants material by Vasisht et al. (2016) where they documented that China import medicinal plants (HS Code 1211) worth USD 15.7 million from Nepal, compared to USD 3.4 million import by India. Pyakurel and Oli (2013) in their study in eastern Nepal documented export of Ophiocordyceps sinensis, Fritillaria cirrhosa, Paris polyphylla, Neopicrorhiza scrophulariiflora and Swertia chirayita towards China.

More specifically, China, including other south-east Asian countries/autonomous territory (Singapore, Hong Kong and Viet Nam) are the major destinations for the most expensive high-value MAP products, such as Ophiocordyceps sinensis, Paris polyphylla and Fritillaria cirrhosa among others growing mainly at high elevations. In fact, high Himalayan 
MAPs always remain most potential resources for livelihood and economy for mountain people (Olsen and Larsen 2003; Olsen 2005b). Overweighing all other high Himalayan MAPs, Ophiocordyceps sinensis alone proves to be the most important species for economic return (Shrestha and Bawa 2013, 2014; Thapa et al. 2014). The popularity and increase use of high Himalayan herbs in official pharmacopeia of Tibetan and Chinese medicines is related to their high demand from Chinese pharmaceutical industries (Shengji et al. 2009; Zhang et al. 2014). Likewise, rising household income in China might cause the behavioral change to shift from modern medication to safer herbal treatment, but the actual reason remains inadequately known. There are, however, few evidences (e.g., Chao and Wade 2008; Shih et al. 2012), which show that high income helped to shift from conventional to herbal medication (Shih et al. 2012).

One of the major problems in accurately estimating the export value of Nepalese MAPs is the lack of complete trade data. MAPs are exported illegally and undocumented due to the lack of strict control at Nepal's highly porous borders (with India towards south and China towards north), making it possible for undocumented cross-border trade (Olsen and Larsen 2003; Olsen 2005b). Therefore, the volume and value of MAP trade based on official data is an underestimation of actual trade as a significant proportion of which is carried out through secret but illegal channels. Our study also records the underestimation in DoF data compared to UN COMTRADE statistics giving an impression that underestimation is common in Nepal (e.g., Malla et al 1995; Olsen and Larsen 2003; Olsen 2005a,c; Environmental Resource Institute 2011). Even the species banned for harvesting, such as Dactylorhiza hatagirea and several species of lichens are involved in commercial trade though illegally (Olsen and Larsen 2003; Uprety et al. 2016). Study showed that $D$. hatagirea has a contribution of about $20 \%$ of total value to rural collectors (Olsen and Helles 1997a). This is a challenge to the effectiveness of policies and regulations formulated for the conservation of threatened species. Hence, imposing restrictions only does not seem to be the most needed approach; there should be regular monitoring of such species to check effectiveness of regulatory measures. A strict measure of checking is a need at the borders. Also, as most of the plant products are supplied dry, it becomes difficult to delineate the species if not have proper knowledge; hence, it would be a good measure if proper training and awareness is provided to the concerned authorities.

The gap in appropriate documentation of commercial MAPs has also created distractions. Bhattarai and Ghimire (2006) documented a total of 143 species of commercial MAPs stating that there is a possibility of addition to the list. A complete and timely revision of the list for traded MAPs is needed for the effectively addressing this sector. Many species are adulterants and traded under the same common name so they are not in the legal documentation. It not only harms the quality of the product in trade but also misleads the quantification of species harvested and its availability. On the other hand, the species which is actually facing over harvesting does not come up to attention and is overshadowed from possible management.

However, with inadequate revision in the trade data, implementation of long-made policies is apparently not effective. Trade of MAPs seems to be pivotal for local economy and national revenue generation, and it is one of the prioritized sectors by the Government of Nepal (Bhattarai and Ghimire, 2006), but it still lacks proper attention and a dedicated research. There is a prominent need of developing strategies for sustainable harvest of wild MAPs (Ghimire 2008) and their commercial cultivation. Cultivation will not only lessen the pressure on wild populations but also ensure a greater supply in the trade and help to uplift the economic status of local communities and downsize poverty. With the sprouting pharmaceutical companies and attraction towards natural products, the trade of MAPs is undeniably one of the prosperous future prospects for national economy for Nepal. This is also advocated by Olsen (2003) previously, suggesting the government to create incentives for the promotion of value addition through processing.

\section{Conclusions}

We have analyzed the export of Nepalese MAPs using the UN COMTRADE data, which gives insight about the export volume and value of different product categories under MAPs. Amongst the different product categories, medicinal plants and spices and flavors are the most important export commodities under MAPs category and shares major percentage, both in terms of volume and value. Though Nepalese MAPs are exported in more than 50 countries, India is still dominating the import in terms of volume but Chinese interest in high valued MAPs has significantly increased the import value. Nepal can reap maximum benefit from growing international demand of MAPs but to formalize the sector there are few fundamental aspects that needs to be addressed. Government has to impose strict check in borders to minimize the underestimation, train concerned authorities (in districts and borders) in proper identification of MAPs products and help to develop speciesspecific 8- and 10-digit HS Codes for proper documentation of imports and exports of MAPs products.

\section{Acknowledgements}

We acknowledge the Department of Plant Resources (DPR), Ministry of Forest and Soil Conservation for financial support. We are thankful to Sunil Kumar Acharya and other staff at DPR for their critical comments and suggestions on the earlier version of the report. 


\section{Reference}

Banjade M.R. and Paudel N.S. 2008. Economic potential of nontimber forest products in Nepal: Myth or Reality? Journal of Forest and Livelihood, 7: 36-48.

Barnes S. and Prasain J. 2005. Current progress in the use of traditional medicines and nutraceuticals. Current Opinion in Plant Biology, 8: 324-328.

Bhattarai K.R. and Ghimire M. 2006. Commercially important medicinal and aromatic plants of Nepal and their distribution pattern and conservation measure along the elevation gradient of the Himalayas. Banko Janakari, 16: 3-13.

Chao M.T. and Wade C.M. 2008. Socioeconomic factors and women's use of complementary and alternative medicine in four racial/ ethnic groups. Ethnicity and Disease, 18: 65-71.

DoF. 2006-2015. Hamro Ban (2006-2015 series). Department of Forests, Ministry of Forest and Soil Conservation, Government of Nepal, Kathmandu, Nepal. (in Nepali).

DPR. 2006. Prioritized Medicinal Plants for the Economic Development in Nepal. Department of Plant Resources, Ministry of Forest and Soil Conservation, Government of Nepal, Thapathali, Kathmandu, Nepal. (in Nepali).

Edward D.M. 1996. Non-Timber Forest Products from Nepal: Aspect of the Trade in Medicinal and Aromatic Plants. FORESC Monograph. Ministry of Forests and Soil Conservation, Kathmandu, Nepal.

Environmental Resources Institute 2011. Employment in Nepal's Forestry Sector. LFP/ERI/GoN-MoFSC, Kathmandu, Nepal.

Ghimire S.K. 1999. Medicinal and aromatic plants in the Nepal Himalaya: status, use sale and conservation. The Wildlife, 1: $42-52$.

Ghimire S.K. 2008. Medicinal plants in the Nepal Himalaya: current issues, sustainable harvesting, knowledge gaps and research priorities. In: Medicinal Plants in Nepal: An Anthology of Contemporary Research (P.K. Jha, S.B. Karmacharya, M.K. Chhetri, C.B. Thapa and B.B. Shrestha, eds.), pp. 25-42. Ecological Society (ECOS), Nepal.

Ghimire S.K., McKey D. and Aumeeruddy-Thomas Y. 2005. Conservation of Himalayan medicinal plants: Harvesting patterns and ecology of two threatened species, Nardostachys grandiflora DC. and Neopicrorhiza scrophulariiflora (Pennell) Hong. Biological Conservation, 124: 463-475.

Hamilton A.C. 2004. Medicinal plants, conservation and livelihoods. Biodiversity and Conservation, 13: 1477-1517.

Humagain K. and Shrestha K.K. 2009. Medicinal plants in Rasuwa district, central Nepal: trade and livelihood. Botanica Orientalis, 6: 39-46.

Kunwar R.M., Mahat L., Acharya R.P. and Bussmann R.W. 2013. Medicinal plants, traditional medicine, markets and management in far-west Nepal. Journal of Ethnobiology and Ethnomedicine, 9: 24 [online] URL: https://doi.org/10.1186/1746-4269-9-24.

Malla S.B., Shakya P.R., Rajbhandari K.R., Bhattarai N.K. and Subedi M.N. 1995. Minor Forest Products of Nepal: General Status and Trade. Forest Resource Information system Project, HMG/ FINNIDA, Kathmandu, Nepal.

Maraseni T.N., Shivakoti G.P. Cockfield G. and Apan A. 2006. Nepalese non-timber forest products: an analysis of the equitability of profit distribution across a supply Chain to India. Small-scale Forest Economics, Management and Policy, 5: 191-206.
Marriott B.M. 2000. Functional foods: an ecologic perspective. American Journal of Clinical Nutrition, 71 (suppl.): 1728-1734.

Máthé A. 2015. Introduction: utilization/significance of medicinal and aromatic plants. In: Medicinal and Aromatic Plants of the World: Scientific, Production, Commercial and Utilization Aspects (A. Máthé, ed.), pp. 1-12. Springer Netherlands.

Medicinal Plant Specialist Group. 2007. International Standard for Sustainable Wild Collection of Medicinal and Aromatic Plants (ISSC-MAP). Version 1.0. Bundesamt für Naturschutz (BfN), MPSG/SSC/IUCN, WWF Germany, and TRAFFIC, Bonn, Gland, Frankfurt, and Cambridge (BfN-Skripten 195).

Olsen C.S. 1998. The trade in medicinal and aromatic plants from central Nepal to northern India. Economic Botany, 52: 279-292.

Olsen C.S. 2003. Quantification of the trade in medicinal and aromatic plants in and from Nepal. In: III WOCMAP Congress on Medicinal and Aromatic Plants-Volume 4: Targeted Screening of Medicinal and Aromatic Plants, Economics 678, pp. 29-35.

Olsen C.S. 2005a. Quantification of the trade in medicinal and aromatic plants in and from Nepal. Acta Horticulturae, 678: 29-35.

Olsen C.S. 2005b. Valuation of commercial central Himalayan medicinal plants. Ambio, 34: 607-610.

Olsen C.S. 2005c. Trade and conservation of Himalayan medicinal plants: Nardostachys grandiflora DC. and Neopicrorhiza scrophulariiflora (Pennell) Hong. Biological Conservation, 125: 505-514.

Olsen C.S. and Helles F. 1997a. Making the poorest poorer: policies, laws and trade in medicinal plants in Nepal. Journal of World Forest Resource Management 8: 137-158.

Olsen C.S. and Helles F. 1997b. Medicinal plants, markets, and margins in the Nepal Himalaya: trouble in paradise. Mountain Research and Development 17: 363-374.

Olsen C.S. and Larsen H.O. 2003. Alpine medicinal plant trade and Himalayan mountain livelihood strategies. The Geographical Journal, 169: 243-254.

Olsen C.S. and Larsen O.H. 2003. Alpine medicinal plant trade and Himalayan mountain livelihood strategies. The Geographical Journal, 169: 243-254.

Pieroni A., Quave C.L., Villanelli M.L., Manginod P., Sabbatini G., Santini L., Boccetti T., Profili M., Ciccioli T., Rampad L.G., Antonini G., Girolamini C., Cecchi M. and Tomasi M. 2004. Ethnopharmacognostic survey on the natural ingredients used in folk cosmetics, cosmeceuticals and remedies for healing skin diseases in the inland Marches, Central-Eastern Italy. Journal of Ethnopharmacology, 91: 331-344.

Pyakurel D. and Oli B.R. 2013. Market Study of Tradeable and Economically Important Medicinal and Aromatic Plants of Eastern Nepal (Using Value Chain Approach). Unpublished Report for Department of Plant Resources, Ministry of Forest and Soil Conservation, Government of Nepal, Kathmandu, Nepal.

Schippmann U., Leaman D.J. and Cunningham A.B. 2002. Impact of cultivation and gathering of medicinal plants on biodiversity: global trends and issues. In: Biodiversity and the ecosystem approach in agriculture, forestry and fisheries. http://www.fao. org/documents/show_cdr.asp?url_file=//DOCREP/005/Y4586E/ y4586e 08.htm. FAO, Rome, Italy.

Shengji P., Huyin H. and Lixin Y. 2009. Medicinal plants and their conservation in china with reference to the Chinese Himalayan region. Asian Medicine, 5: 273-290. 
Shih C.C., Liao C.C., Su Y.C., Yeh T.F. and Lin J.G. 2012. The association between socioeconomic status and traditional chinese medicine use among children in Taiwan. BMC Health Services Research, 12: 27 [online] URL: http://www.biomedcentral. com/1472-6963/12/27.

Shrestha U.B. and Bawa K.S. 2013. Trade, harvest, and conservation of caterpillar fungus (Ophiocordyceps sinensis) in the Himalayas. Biological Conservation, 159: 514-520.

Shrestha U.B. and Bawa K.S. 2014. Economic contribution of Chinese caterpillar fungus to the livelihoods of mountain communities in Nepal. Biological Conservation, 177: 194-202.

Subedi A., Kunwar B., Choi Y., Dai Y., van Andel T., Chaudhary R.P., deBoer H.J., Gravendeel B. 2013. Collection and trade of wild-harvested orchids in Nepal. Journal of Ethnobiology and Ethnomedicine, 9: 64 [online] URL: http://doi.org/10.1186/17464269-9-64.

Subedi B.P. 2006. Linking Plant-Based Enterprises and Local Communities to Biodiversity Conservation in Nepal Himalaya. Adroit Publishers, New Delhi, India.
Thapa B.B., Panthi S., Rai R.K., Shrestha U.B, Aryal A., Shrestha S., Shrestha B. 2014. An assessment of yarsagumba (Ophiocordyceps sinensis) collection in Dhorpatan Hunting Reserve, Nepal. Journal of Mountain Science, 11: 555-562.

UNSD 2015. UN COMTRADE. United Nations Statistics Division, United Nations, New York, USA.

Uprety Y., Poudel R.C., Gurung J., Chettri N. and Chaudhary R.P. 2016. Traditional use and management of NTFPs in Kangchenjunga Landscape: implications for conservation and livelihoods. Journal of Ethnobiology and Ethnomedicine, 12: 19 [online) URL: http://doi.org/10.1186/s13002-016-0089-8.

Vasisht K., Sharma N. and Karan M. 2016. Current perspective in the international trade of medicinal plants material: an update. Current Pharmaceutical Design, 22: 4288-4336.

Zhang D., Duan L. and Zhou N. 2014. Market survey on traditional medicine of the third month fair in Dali prefecture in Yunnan province, southwest China. African Journal of Traditional, Complementary and Alternative Medicines, 11: 377-401. 